www.jmscr.igmpublication.org

Impact Factor (SJIF): 6.379

Index Copernicus Value: 71.58

ISSN (e)-2347-176x ISSN (p) 2455-0450

crossrefDOI: https://dx.doi.org/10.18535/jmscr/v6i7.139

Journal Of Medical Science And Clinical Research

\title{
Comparative Study of commonly sexually transmitted disease (Syphilis and gonorrhoea) in the Dhanbad District of Jharkhand
}

\author{
Authors \\ Dr Sujeet Kumar Tiwary ${ }^{1}$, Dr Siyavar Sharan², Dr Binay Kumar Singh ${ }^{3}$ \\ Dr Sunil Kumar Sinha ${ }^{4}$, Dr Rajendra Kumar ${ }^{5}$ \\ Corresponding Author \\ Dr Siyavar Sharan (Associate Professor)
}

\begin{abstract}
Sexually transmitted disease which spreads mainly by sex with infected persons either by Anal and oral sex. More than 30 different Types of bacteria, viruses and parasites can be transmitted through sexual activity but most commonly is syphilis and gonorrhoea ${ }^{[1,2]}$ Syphilis is caused by the Treponema pallidum Bacteria .syphilis is classified into three stages- primary, secondary ,tertiary. After patients acquired infection; patients suffer from many serious Health problems, if it is not treated Properly and Timely ,Eventually, the Patients with stage of tertiary syphilis will die ${ }^{.[3,4]}$ Second most common infection of STD is Gonorrhoea, which is caused by the Neisseria gonorrhoea. Neisseria Gonorrhoea is spread through sexual contact with an infected person ${ }^{[5,6]}$

Materials and Method: This study carried out from 28 April 2016 to 29 April 2018 in the Patliputra Medical College \& Hospital Dhanbad. A total of 700 samples were collected from the STD suspected patients, with or without any complaints as enunciated by WHO in its syndromic approach for the diagnosis of STI (WHO, 2001 and Choudhry, et al 2010) were includes as subjects. Three hundred (230 Males and 70 Females) examined for syphilis, while four hundred (280 males and 120 Females) examined for gonorrhoea followed up patients were excluded from the study. Detailed history and clinical features were recoded from all the patients. All samples were screened for common STIs, by standard microbiological Methods.

Result: In this comparative study we found the total number of gonorrhoea positive male patients 95 and female 35 , overall total gonorrhoea positive 130, and the total syphilis positive male 28 and female 34, over all syphilis positive 62, we are found this gonorrhoea infection is more than higher for syphilis.

Laboratory identification of Syphilis and Gonorrhoea: All suspected patients both Male and female Urethral Swab, High Vaginal swab and Endocervical Swab were collected in the Department of microbiology of Patliputra Medical college and Hospital. Direct examination with use of wet preparation method. Gram staining method was carried out on both high vaginal swab (HVS) and Endocervical swab (ECS) and examined 100x objective under oil immersion and identified Gram negative diplococci shape gonorrhoea. Endocervical swab specimens were inoculated into blood agar and Thayer Martin agar while High vaginal swab specimen were inoculated into blood agar. After 48 hours all inoculated specimens examine direct microscopy in the help of grams stains and identified diplococci Shape gonorrhoea.

Serological test procedure use for diagnosis of syphilis, From All patients 3-5 ml of Blood samples were collected in a sterile plastic containers and separated serum from all samples and used within two days for screening tests of syphilis. Other were frozen for confirmatory tests. Syphilis antibodies were tested for using syphilis ultra - rapid tests strips.
\end{abstract}

Data analysis: All Data were analysed with standard statistical method, Percentage were computed for all variables. Result were presented in the form of table \& column.

Keyword: Gonorrhoea, Syphilis, Infection, Mucous, Neurological. 


\section{JMSCR Vol||06||Issue||07||Page 843-847||July}

\section{Introduction}

Sexually transmitted disease are infectious disease transmitted by sexual contact \& activity. its represents a major public health problem for a number of years .sexually Transmitted infection are spread through contact with infected body fluids such as blood and blood products ,vaginal fluids ,or semen. ${ }^{[7,8]}$ They can also be spread through contact with infected skin or mucous membrane. Gonorrhoea \& syphilis is a common sexually transmitted disease ${ }^{[9,10]}$ Gonorrhoea is a caused by the Neisseria gonorrhoea, can be passed from mother to baby during delivery. Untreated, gonorrhoea can increase the risk of acquiring or transmitting Gonorrhoea infection both Men and women's slightly different symptoms, infected men white, yellow or green urethral discharge , resembling pus, pain in the testicles, painful frequent urination ${ }^{[11,12]}$ infected Women's painful sexual intercourse, fever yellow and green vaginal discharge, vomiting and abdominal pain, painful or frequent urination. ${ }^{[13,14]}$ Syphilis is most commonly spread through sexual activity, syphilis infection caused by the Treponema pallidum. ${ }^{[15,16]}$ The symptoms of syphilis vary depending in which of the four stages. It's present as a primary, secondary, latent and tertiary. Primary syphilis present with a single chancre but there may be multiple sores. ${ }^{[18]}$ In Secondary syphilis a diffuse rash, which frequently involves the palms of the hands and soles of the feet. In latent syphilis, which can last for years, there are a few or no symptoms. In tertiary syphilis there are gammas, which causes neurological and heart complication.

Table-1. Total Number of Gonorrhoea positive and Negative Male and Female $(\mathrm{N}=700)$

\begin{tabular}{|c|c|c|c|c|c|c|c|c|c|}
\hline \multirow{2}{*}{$\begin{array}{l}\text { Age } \\
\text { Group }\end{array}$} & \multicolumn{3}{|c|}{ Number of Total Patients } & \multicolumn{3}{|c|}{ Number of Gonorrhoea Positive } & \multicolumn{3}{|c|}{ Number. Of Gonorrhoea Negative } \\
\hline & Male. & Female. & Total \% & Male. & Female. & Total. \% & Male & Female & Total \%. \\
\hline $15-20$ & $\begin{array}{c}62 \\
13.50 \%\end{array}$ & $\begin{array}{c}24 \\
9.95 \%\end{array}$ & $\begin{array}{c}86 \\
12.38 \%\end{array}$ & $\begin{array}{c}08 \\
8.42 \%\end{array}$ & $\begin{array}{c}03 \\
8.57 \%\end{array}$ & $\begin{array}{c}11 \\
8.46 \%\end{array}$ & $\begin{array}{c}54 \\
14.83 \%\end{array}$ & 21 & $\begin{array}{c}75 \\
13.15 \%\end{array}$ \\
\hline 21-26 & $\begin{array}{c}69 \\
15.03 \%\end{array}$ & $\begin{array}{c}34 \\
14.10 \%\end{array}$ & $\begin{array}{c}103 \\
14.71 \%\end{array}$ & $\begin{array}{c}12 \\
12.63 \%\end{array}$ & $\begin{array}{c}05 \\
14.28 \%\end{array}$ & $\begin{array}{c}17 \\
13.07 \%\end{array}$ & $\begin{array}{c}57 \\
15.65 \%\end{array}$ & 29 & $\begin{array}{c}86 \\
15.08 \%\end{array}$ \\
\hline $27-33$ & $\begin{array}{c}155 \\
33.76 \% \\
\end{array}$ & $\begin{array}{c}63 \\
26.14 \% \\
\end{array}$ & $\begin{array}{c}218 \\
21.14 \%\end{array}$ & $\begin{array}{c}36 \\
37.89 \%\end{array}$ & $\begin{array}{c}13 \\
37.14 \%\end{array}$ & $\begin{array}{c}49 \\
37.69 \%\end{array}$ & $\begin{array}{c}119 \\
32.69 \%\end{array}$ & 50 & $\begin{array}{c}169 \\
29.64 \%\end{array}$ \\
\hline $34-40$ & $\begin{array}{c}107 \\
23.31 \%\end{array}$ & $\begin{array}{c}89 \\
36.92 \%\end{array}$ & $\begin{array}{c}196 \\
28 \%\end{array}$ & $\begin{array}{c}29 \\
30.52 \%\end{array}$ & $\begin{array}{c}09 \\
25.71 \%\end{array}$ & $\begin{array}{c}38 \\
29.23 \%\end{array}$ & $\begin{array}{c}78 \\
21.42 \%\end{array}$ & 80 & $\begin{array}{c}158 \\
27.71 \%\end{array}$ \\
\hline $41-47$ & $\begin{array}{c}45 \\
9,80 \%\end{array}$ & $\begin{array}{c}22 \\
9.12 \%\end{array}$ & $\begin{array}{c}67 \\
9.57 \%\end{array}$ & $\begin{array}{c}07 \\
7.36 \%\end{array}$ & $\begin{array}{c}03 \\
8.57 \&\end{array}$ & $\begin{array}{c}10 \\
7.69 \%\end{array}$ & $\begin{array}{c}38 \\
10.43 \%\end{array}$ & 19 & $\begin{array}{c}57 \\
10 \%\end{array}$ \\
\hline $\begin{array}{l}48-54 \\
\& \text { above }\end{array}$ & $\begin{array}{c}21 \\
4.57 \%\end{array}$ & $\begin{array}{c}09 \\
3.73 \%\end{array}$ & $\begin{array}{c}30 \\
4.28 \%\end{array}$ & $\begin{array}{c}03 \\
3.15 \%\end{array}$ & $\begin{array}{c}02 \\
5.71 \%\end{array}$ & $\begin{array}{c}05 \\
3.84 \%\end{array}$ & $\begin{array}{c}18 \\
4.94\end{array}$ & 07 & $\begin{array}{c}25 \\
4.38 \%\end{array}$ \\
\hline Total & 459 & 241 & 700 & $\begin{array}{c}95 \\
13.57\end{array}$ & $\begin{array}{c}35 \\
5 \%\end{array}$ & $\begin{array}{c}130 \\
18.57 \%\end{array}$ & 364 & 206 & 570 \\
\hline
\end{tabular}

Table- 2.Total Number of Syphilis positive and Negative Male \& Female (N=700)

\begin{tabular}{|c|c|c|c|c|c|c|c|c|c|}
\hline \multirow[t]{2}{*}{ Age Group } & \multicolumn{3}{|c|}{ Number of Total Patient } & \multicolumn{3}{|c|}{ No .of Syphilis Positive } & \multicolumn{3}{|c|}{ No. of Syphilis Negative } \\
\hline & Male & Female & Total & Male & Female & Total & Male & Female & Total \\
\hline $15-20$ & $\begin{array}{c}62 \\
13.5\end{array}$ & $\begin{array}{c}24 \\
9.95\end{array}$ & $86(12.28 \%)$ & $\begin{array}{c}\mathrm{O} 2 \\
7.14\end{array}$ & $\begin{array}{c}03 \\
8.82\end{array}$ & $\begin{array}{c}05 \\
8.06\end{array}$ & $\begin{array}{c}60 \\
13.92\end{array}$ & $\begin{array}{c}21 \\
10.14\end{array}$ & $\begin{array}{c}81 \\
12.69\end{array}$ \\
\hline 21- 26 & $\begin{array}{c}69 \\
15.03\end{array}$ & $\begin{array}{c}34 \\
14.10\end{array}$ & $\begin{array}{c}103 \\
(14.71 \%)\end{array}$ & $\begin{array}{c}05 \\
17.85 \\
\end{array}$ & $\begin{array}{c}07 \\
20.58\end{array}$ & $\begin{array}{c}12 \\
19.35\end{array}$ & $\begin{array}{c}64 \\
14.84\end{array}$ & $\begin{array}{c}27 \\
13.03\end{array}$ & $\begin{array}{c}91 \\
14.26\end{array}$ \\
\hline $27-33$ & $\begin{array}{c}155 \\
33.76\end{array}$ & $\begin{array}{c}63 \\
26.14\end{array}$ & $\begin{array}{c}218 \\
31.48 \%\end{array}$ & $\begin{array}{l}07 \\
25\end{array}$ & $\begin{array}{c}09 \\
26.47\end{array}$ & $\begin{array}{c}16 \\
25.80\end{array}$ & $\begin{array}{c}148 \\
34.33\end{array}$ & $\begin{array}{c}54 \\
26.08\end{array}$ & $\begin{array}{c}202 \\
31.66\end{array}$ \\
\hline $34-40$ & $\begin{array}{c}107 \\
23.31\end{array}$ & $\begin{array}{c}89 \\
36.92\end{array}$ & $\begin{array}{l}196 \\
28 \%\end{array}$ & $\begin{array}{c}09 \\
32.14\end{array}$ & $\begin{array}{c}10 \\
29.41\end{array}$ & $\begin{array}{c}19 \\
30.64\end{array}$ & $\begin{array}{c}98 \\
22.73\end{array}$ & $\begin{array}{c}79 \\
38.60\end{array}$ & $\begin{array}{c}177 \\
27.74\end{array}$ \\
\hline $41-47$ & $\begin{array}{c}45 \\
9.80\end{array}$ & $\begin{array}{c}22 \\
9.12\end{array}$ & $\begin{array}{c}67 \\
9.57 \%\end{array}$ & $\begin{array}{c}03 \\
10.71\end{array}$ & $\begin{array}{c}02 \\
5.88\end{array}$ & $\begin{array}{c}05 \\
8.06\end{array}$ & $\begin{array}{c}42 \\
9.74\end{array}$ & $\begin{array}{c}20 \\
9.66\end{array}$ & $\begin{array}{c}62 \\
9.71\end{array}$ \\
\hline $\begin{array}{c}48-54 \\
\text { \&ahove. }\end{array}$ & $\begin{array}{c}21 \\
4.57 \\
\end{array}$ & $\begin{array}{c}09 \\
373 \\
\end{array}$ & $\begin{array}{c}30 \\
428 \%\end{array}$ & $\begin{array}{c}02 \\
714 \\
\end{array}$ & $\begin{array}{c}03 \\
882 \\
\end{array}$ & $\begin{array}{c}05 \\
806 \\
\end{array}$ & $\begin{array}{c}19 \\
4.40 \\
\end{array}$ & $\begin{array}{c}06 \\
289 \\
\end{array}$ & $\begin{array}{c}25 \\
391\end{array}$ \\
\hline Total. & 459 & 241 & 700 & $\begin{array}{l}28 \\
4 \%\end{array}$ & $\begin{array}{c}34 \\
4.85 \%\end{array}$ & $\begin{array}{c}62 \\
8 .-85 \%\end{array}$ & 431 & 207 & 638 \\
\hline
\end{tabular}




\section{Result}

According to table 1. In our study a total number of 700 suspected patients of syphilis and gonorrhoea samples were collected and thoroughly investigated by the Microbiological standard procedure in the department of microbiology of the Patliputra Medical College and Hospital. In this study we found that the total number of male patients were 459 and total number of female patients were 241. We found that prevalence of gonorrhoea is much higher than syphilis. In the age group of 15- 20 the total numbers of male patients were 62 and female patients were 24 and total numbers of both male and female were 86 . Our investigation found total positive number of Male gonorrhoea patients is 08 and female gonorrhoea patients is 03 and total number of both males and female were 11 . The age group 21 to 26 the total numbers of male patients were 69 and female patients were 34, the total number of both male and females patients were 103, and the total number of gonorrhoea positive male patients were 12 and female gonorrhoea positive patients 05 , the total both male and females were 17.the age group of 27 to33 male patients were 155 and female patients were 63 and overall total is 218 in which 36 males were positive and 13 females were positive and total number of positive patients were 49 . The age group of 34 to 40 total number of male patients 107 and female is 89 and over all total number of both male and females were 196 in which 29 males were positive and 09 females are positive. The age group of 41 to 47 the number of male patients were 45 and female patients were 22 and overall number is 67 in which male positive patients were 07 and female positive patients is 03 , and the total number of positive patients were 10. In the last age group of 48 to 54 and above number of male patients were 21 and females patients were 09 and total number is 13 in which 03 males patients were positive and 02 females patients were positive and overall positive patients is 05 .
According to table 2. Show the age specific distribution of syphilis and age group of 15 t0 20 the number of male patients 62 and female 24 and overall number is 86 , in which male Positive patients 02 and female positive patients 03 . The second age group 21 to 26 the total number of Male patients 69 and female 34 and over all 103, in which male positive 05 and female positive 07. The third age group 27 to 33 , the total male patients 155 and female 63 and overall 218, in which male positive 07 and female 09 , overall positive 16. The fourth age group 34 to 40 the total number of male patients 107 and female 89, overall 196, in which male positive 09 and female 10,overall positive 19 . The Five age group 41 to 47 , the total male patients 45 and female 22 ,overall 67, in which the total male positive 03 and female positive 02 , overall total positive 05 . The six age group 48-54 and above total male patients 21 and female 09 , overall total 30 , in which the total male positive 02 and female 03 , overall positive 05 . In this comparative study of syphilis and gonorrhoea. We found gonorrhoea infection is more than higher for syphilis.

\section{Discussion}

The result of this study have demonstrated the endemicity and occurrence of significant levels of sexually transmitted infection in patients in Dhanbad district of Jharkhand. The STI isolates recovered from the subject include, Treponema pallidum (Syphilis) $8.85 \%$ and N. gonorrhoea $18.57 \%$.

In this study $8.85 \%$ prevalence of Treponema Pallidum (Syphilis) was reported. VDRL test reactive strip samples found significant Treponema antibodies in 05 of them. Absence of significant trepononemal antibodies in other samples tested with VDRL strips may suggest a non-syphilitic regain antibody production or cross reactions with endemic Trepononemal infection such as yaws, Pinta, bejel the detection of these false confirmatory test for syphilis, especially as this is not the use in most hospital. From the study, there was significant difference $(\mathrm{P}<0.05)$ in 
STI positive and sex subject. it was observed that Males 95 (13.57\%) had higher prevalence rate of N. gonorrhoeae compared to the female 35 (5\%) and also females $34(4.85 \%)$ had higher prevalence rate of Pallidum to the Males 28 (4\%). Among the different age groups investigate $\mathrm{N}$. gonorrhoea distribution was highest among the (27 to 33) years old in this study, the peak age group of subject positive for $\mathrm{N}$ gonorrhoea ranged from (48 to 54) \& above Years (3.84\%), while the peak age group of subject positive for T. Pallidium ranged from (48 to 54) above years $(8,06 \%)$ and this study we observed gonorrhoea and syphilis an important public health problem in Dhanbad district. Our study suggested proper education to prevent gonorrhoea and syphilis may be more effective especially in the teenager male and females. Gonorrhoea can be prevented with the use of condoms for vaginal or anal intercourse, having sex with only one person who is uninfected and avoid contact with any sores on the genitals.

\section{Conclusion}

This study shows that incidence and prevalence of the gonorrhoea and syphilis is most common STI infection in Dhanbad urban and ruler areas.

\section{Reference}

1. Shapiro LH, Lentz JW. Clinical evaluation of treatment of gonorrhea in the female. Am J Obstet Gynecol. 1967 Apr 1; 97(7):968-973. [PubMed]

2. Shapiro LH, Lentz JW. Final report on the effectiveness of oxytetracycline in the treatment of Gonorrhoean females. Am J Obstet Gynecol. 1966 Feb 15; 94(4):536538.[PubMed]

3. Department of governmental medical services. Title XIX: Medical Assistance. JAMA. 1966 Jan 10; 195 (2):137-141. [PubMed]

4. Sylvester L, Gallia Z. "Instant treatment" ("treatment minute") of gonorhoea with a new ox Tetracycline Derivate-doxycycline (preliminary report). Into $Z$
Kiln Pharmacology There Toxically. 1968 Jul; 1(5):401-403. [PubMed].

5. Domescik G, McLane DG, Scotti A, Mackey DM. Use of a single dose of doxycycline monohydrate Fortreatinggonorrhoeal urethritis in men. Public Health Rep. 1969 Feb; 84(2):182-183. [PMC Free Article] [PubMed].

6. Rolfs RT, Goldberg M, Sharer RG. Risk factors for syphilis: cocaine use and prostitution. Am J Public Health. 1990 Jul; 80(7):853-857. [PMC free article] [PubMed].

7. Rothenberg RB. The geography of gonorrhea. Empirical demonstration of core group Transmission. Am J Epidemiology. 1983 Jun; 117(6):688694. [PubMed].

8. Potterat JJ, Rothenberg RB, Woodhouse DE, Muth JB, Pratts CI, Fogle JS., 2nd gonorrhoea asa social disease. Sex Transm Dis. $1985 \quad$ Jan-Mar; 12(1):2532 [PubMed].

9. Gershan KA, Rolfs RT. Diverging gonorrhea and syphilis trends in the 1980s: are they Real? Am J Public Health. 1991 Oct; 81(10):1263-1267. [PMC free article] [PubMed].

10. Webster LA, Berman SM, Greenspan JR. Surveillance for gonorrhea and primary and Secondary syphilis among adolescents, United States--19811991. MMWR CDC Surveill Summ. 1993 Aug 13; 42(3):1-11. [PubMed].

11. Zenilman JM, Bonner M, Sharp KL, Rabb JA, Alexander ER. Penicillinase-producing Neisseria Gonorrhoeae in Dade County, Florida: evidence of core-group transmitters and the impact of Illicit antibiotics. Sex Transm Dis. 1988 JanMar; 15(1):45-50. [PubMed]

12. Rothenberg RB, Potterat JJ. Temporal and social aspects of gonorrhea transmission: the force of Infectivity. Sex Transm Dis. 1988 Apr-Jun; 15(2):8892. [PubMed] 
13. Anderson RM, May RM. Epidemiological parameters of HIV transmission. Nature. $1988 \quad$ Jun 9;333(6173):514519. [PubMed]

14. May RM, Anderson RM. Transmission dynamics of HIV infection. Nature. 1987 Mar 12; 326(6109):137-142. [PubMed].

15. Burnham RC, Plummer FA. A general model of sexually transmitted disease epidemiology and its Implications for control. Med Clan North Am. 1990 Nov; 74(6):1339-1352. [PubMed]

16. Rice RJ, Aral SO, Blount JH, Zaidi AA. Gonorrhoea in the United States 19751984: is the giant only sleeping? Sex Transm Dis. 1987 Apr-Jun; 14(2):8387. [PubMed].

17. Garnett GP, Anderson RM. Contact tracing and the estimation of sexual mixing patterns: the epidemiology of gonococcal infections. Sex Transm Dis. $1993 \quad$ Jul-Aug; 20(4):181191. [PubMed]

18. Rothenberg R, Bross DC, Vernon TM. Reporting of gonorrhoea by private physicians: a behavioural study. Am $J$ Public Health. 1980 Sep; 70(9):983986. [PMC free article] [PubMed]. 